\title{
Continuance Usage Intention of Gojek Application in Surabaya
}

\author{
Mariza Kanti Wiryawan ${ }^{1}$, Dudi Anandya ${ }^{2}$ and Christina Rahardja ${ }^{3}$ \\ \{crhonantha@gmail.com ${ }^{1}$ \} \\ ${ }^{1}$ Faculty of Business and Economics Alumnae, University of Surabaya, Indonesia \\ ${ }^{2,3}$ Faculty of Business and Economics University of Surabaya, Indonesia
}

\begin{abstract}
This study aims to examine the variables influence on continuance usage intention. GOJEK application as an object to be observed. A quantitative and causal research with purposive sampling method was used in this study and the research approach is personal survey in Surabaya. Total respondents were 306 who have used GOJEK Application for at least three times for the past three months. We used structural equation modeling (SEM) analysis within IBM SPSS 21.0 and IBM SPSS AMOS 21 for Windows. This research results showed that users' perceived usefulness is the key determinant of GOJEK Application continuance usage intention. The results contribute to more understanding the drivers of GOJEK apps that enhance the continuance intention of GOJEK apps usage in Indonesia.
\end{abstract}

Keywords: Perceived Usefulness, Attitude, Satisfaction, GOJEK Apps Continuance Intention

\section{Introduction}

Today's information era, the usage of smart-phones and mobile application has become increasingly common (Jain, Kumar, \& Singla, 2014). In addition, it becomes part of human life (Soemantadiredja et al., 2015). Different kinds of application in the smartphone change the ways of life in many ways (Chan et al.,2016). The mobile applications are in form of financial services, airline booking services, shopping and new service on taxis ordering (Keong, 2016), which in this term is called by Mobile Taxi Booking Application. By using Mobile Taxi Booking Application, the available nearby taxi can pick up users without worrying about the traffic contingent and air pollution (Weng et al., 2017). Users can fix the locations by GPS or typing in the target location, which drivers can reach easily (Chan et al., 2016).

According to Kompas.com (2017), Mobile Taxi Booking Application is a must downloaded application since it helps user to change people's habit from using private transportation to public transportation.

In Indonesia, there are several business players that provide Mobile Taxi Booking Application, which are GO-JEK, and GrabTaxi (Noviandari, 2015). According to Katadata Indonesia (2016), Mobile Taxi Booking Application that are used in Indonesia are GOJEK by $85.22 \%$, Grab by $66.24 \%$, Uber by $50.06 \%$ and the rest with a very low percentage are similar services initiated by local players.

This research model use four model as the general theories in earlier studies, which are the Technology Acceptance Model (TAM), Expectation Confirmation Model (ECM), Cognitive Model (COGM), and Technology Continuance Theory (TCT) (Weng et al., 2017). This study attempts to develop new research model include compatibility and perceived playfulness as factors influencing users' attitude. According to Ozturk et 
al (2016), compatibility is the level of an information system or technology fits users' lifestyle. Perceived playfulness is the level of fun during the usage of application (Lee et al., 2015).

\section{Literature Review And Hyphoteses Development}

Davis (1980) developed Technology Acceptance Model (TAM) for the information system area. TAM was developed to explain and predict the users' acceptance of information technology (Moon \& Kim, 2001). Expectation Confirmation Model (ECM) was frequently used in studying users' behavior regarding an information system postadoption environment (Kim, 2010). ECM was also widely used in the consumer behavior literature to study consumer post-purchase behavior, satisfaction and service marketing in general (Oliver, 1980; Bhattacherjee, 2001).

Cognitive model was developed by Oliver (1980) who had proposed both attitude and satisfaction were determinants of behavioral intention (Weng et al., 2017). Development of the cognitive result was largely theoretical but was also affected on emotional affect or attitude (Oliver, 1980). However Oliver (1980) also stated that consumer satisfaction has encouraged several deep explanations of satisfaction cognitions.

Technology Continuance Theory (TCT) gave two central constructs of attitude and satisfaction that was merged into one continuance model and it was possibly applied for users at different stages of the adoption life cycle (Liao et al., 2009). In addition, when considering the various life cycle adoption stages, the TCT represented a significant improvement over the TAM, ECM, and COGM models (Liao et al., 2009).

Attitude refers to individual's general assumption towards a given behavior and was the result of individual beliefs regarding the behavior and its results and the importance attached to such beliefs (Currás-Pérez et al., 2013). Previous researches confirmed the positive effect of attitude on continuance intention (Peng et al., 2014; Keong, 2016).

$\mathbf{H}_{1}$ : Users' attitude towards using GOJEK Application influences users' continuance usage intention.

Satisfaction was a state when individuals feel satisfied, neutral, or dissatisfied in the outcomes of greater, equal to, or below expectations (Amaroso \& Lim, 2017). The more satisfied the users are, then the higher the likelihood users will continue using the current application (Oghuma et al., 2016). Several studies' results about satisfaction and continuance intention are positively accepted (Pham \& Ahammad, 2017; Lee \& Kwon, 2011).

H2: GOJEK Application users' satisfaction positively influences users' continuance usage intention.

Attitude was the constant evaluation of a product or service, and satisfaction was the post-purchase evaluation of a product or service (Iranmanesh et al., 2017). Gilani et al (2016) and Iranmanesh et al (2017) research result's confirmed that satisfaction influenced customer attitude toward using information system.

H3: Users' satisfaction positively influences users' attitudes towards using GOJEK Application.

Perceived usefulness was a construct combined to an assessment of the benefits that result to an individual by using the technology (Ndubisi \& Jantan, 2003). The more benefits users expect from an information system, the more satisfy users are and the higher the probability that users will continue using it (Oghuma et al., 2016). Users will 
always want to keep using a certain application that helps them improve productivity (Bhattacherjee, 2001).

H4: GOJEK Application users' perceived usefulness positively influences users' continuance usage intention.

Perceived usefulness was considered as motivation to play a role particular information system usage, which concerned with performance as consequences of use (Keong, 2016). Percevied usefulness was a construct that has been repeatedly showed to influence attitude (Lee et al., 2013). It was found that positive attitude would turn up when user feel that using a technology would help them to be more productive (Iranmanesh et al., 2017).

H5: Users' perceived usefulness positively influences users' attitudes towards using the GOJEK Application.

Perceived ease of use was defined when the information system was easy to operate and does not involve too much difficulty to operate it (Bashir \& Madhaviah, 2015). Perceived ease of use affects a person's attitude toward using an information system (Lee et al., 2010). When the MTB App's user will become familiar with the features of application, so the ease of use will lose its significance in users attitude towards using the App (Weng et al., 2017). The result supports Taylor and Todd (1995), which it was said that user with experience using the application will overcome the concerns about ease of use.

H6: Users' perceived ease of use positively influences users' attitudes towards using GOJEK Application.

Subjective norm refers to the perceived social demand to perform or not to perform a certain behavior (Ajzen, 1991). When the era of a big data has arrived, the information which consumer accepted was growing rapidly, which leads to decrease in ability of self-judgment (Peng et al., 2014). Users will usually go along with the opinions of users' close relative, friends, or colleagues that have positive opinions about an information system, which was related to user continuance intention (Chen et al., 2018).

H7: GOJEK Application users' subjective norm positively influences users' continuance usage intention.

Many users decide to use MTB App if it was also used by users' friends and it was recommended to them (Weng et al., 2017). Subjective norms were found to influence attitude (Tarkianen \& Sundqvist, 2005).

Hs: Users' subjective norm positively influences users' attitudes towards using GOJEK Application.

Information system was generally discovered as more useful if it was easy to use (Gilani et al., 2017). In addition, Shih (2004) result also confirmed that perceived ease to use directly has the influence to perceived of usefulness.

H9: GOJEK Application users' perceived ease of use positively influences users' perceived usefulness.

Perceived risk was evaluated as an uncertainty concerning the possible negative consequences of using product or services (Srivastava \& Sharma, 2011). Perceived risk refers to consumer's degree of uncertainty regarding the output of a purchase decision (Keong, 2016). Perceived risk plays an important role in use or online purchase behavior since it is related with user perceptions (Currás-Pérez et al., 2013).

$\mathbf{H}_{10}$ : Users' perceived risk negatively influences users' attitudes towards using GOJEK Application. 
When the perceived quality goes beyond the expectation, users' information needs will be completely satisfied and users will get more satisfactory experiences (Xu \& Du, 2018). Lee (2010) stated that users' satisfaction was determined by users' perceived usefulness since users expected benefit from the usage experience, those leads to a positive effect on users' satisfaction.

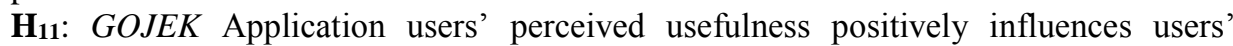
satisfaction.

Confirmation was the degree when actual use confirms the initial expectation (Oghuma et al., 2016). Susanto et al (2016) claimed that confirmation of expectation would increase user satisfaction. Users' satisfaction was determined by the users' confirmation of expectations (Lee, 2010).

H12: GOJEK Application users' confirmation of expectations positively influences users' satisfaction.

Post acceptance of perceived usefulness was affected by users' confirmation level (Bhattacherjee, 2001). Based on the original ECT model, perceived usefulness was influenced by confirmation (Lin et al., 2005). Lee (2010) stated that users' confirmation of expectations will have a positive effect on the perceived usefulness. Based on the above result, the hypothesis has been presented as follows:

H13: GOJEK Application users' confirmation of expectations positively influences users' perceived usefulness.

Vijayasarathy (2004) showed when users find compatibility between an innovation and users' original lifestyle, values, and needs, consumers have more positive attitude. Several studies showed that compability positively correlated and influenced the users' attitude towards using an information system (Peng et al, 2014).

H14: Users' compatibility positively influences users' attitudes towards using GOJEK Application.

Playfulness refers to the level of fun perceived during interactive application use (Lee et al., 2015). When the perceived of playfulness of information system was higher, people tend to have a positive attitude toward behavior (Davis et al., 1992). According to previous research result, perceived playfulness influence attitude (Lee et al, 2015; Ahn et al, 2007).

H15: Users' perceived playfulness positively influences users' attitudes towards using GOJEK Application. 


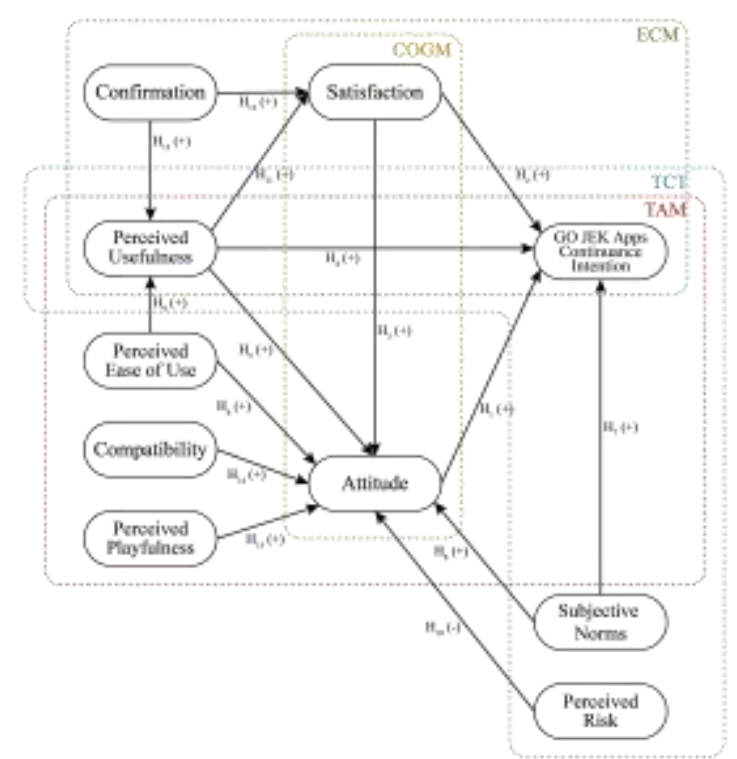

Fig.1. Research Model

\section{Method}

The instrument is used for collecting primary data used is questionnaires that consisted of general questions regarding personal information and questions on 10 measurement variables: confirmation, perceived usefulness, perceived ease of use, perceived risk, satisfaction, attitude, subjective norms, continuance intention, compatibility, and perceived playfulness. The personal information questions consist of gender, age, race, occupational status, academic qualification, monthly family income, average monthly cost, and length of experience in using GOJEK App. Each measurement variable had three to six items, and each items used a five-point numerical scale. This study adopts the non-probability sampling where the probability sample in a targeted population is unknown. However, the unit sampling selection is based on the researcher's personal judgment (Zikmund, 2003:380). The non-probability sampling type that this study uses purposive sampling. It aims to get sample from respondents with specific criteria (Zikmund et al., 2003:382). The population in this study is people who had experienced in using GOJEK Application in Surabaya. The characteristics of respondents are people that have been using GOJEK Application and GO-RIDE or GO$C A R$ service for the last three months and 306 questionnaires were collected.

Validity and reliability tests are done by distributing questionnaires to 30 initial respondents using IBM software SPSS for windows. The CFA model is used to test how well the measure variable represents the construct or to test the validity of the items used in the study. To test the validity of the indicator using the calculation of the standardized loading $(\lambda)$ values and for variable validity test uses AVE (Average Variance Extracted) calculation. Hair et al (2010:709), the standardized loading value must be greater than 0.5 (std.load $\geq 0.5$ ), the AVE value must be greater than 0.5 $(\mathrm{AVE} \geq 0.5)$. 
To test if the model will be accepted or rejected and to test the suitability level of the research model, according to Hair et al (2014) this study might use several indexes; such as CMIN/DF, Root Mean Square of Approximation (RMSEA), Goodness of Fit Index (GFI), Comparative Fit Index (CFI), and Tucker-Lewis Index (TLI). The hypothesis can be accepted if the |t-value| or |C.R.| value is higher than 1.96 (|t-value| or |C.R. $>1.96)$.

\section{Result And Discussion}

There are 306 respondents and total of 132 respondents $(43.1 \%)$ of the respondents have spent between $R p 75,001$ and $R p 100,000$ on GO-RIDE or GO-CAR per month. while 203 respondents $(66.3 \%)$ have spent less than $R p 300,000$ on transportation per month. A total of 180 respondents $(58.8 \%)$ are female. In addition, 222 respondents $(72.5 \%)$ are between 21 and 30 years old and 146 respondents' $(47.7 \%)$ education background are undergraduate, also a total of 135 respondents $(44.1 \%)$ are employee, and 145 respondents $(47.4 \%$ ) have earned between $R p$ 2,600,000 and $R p$ 6,000,000 per month.

CFA measurement is done to know an indicator can be considered as valid if the value of the standardized loading has a value greater than 0.5 .

Table 1: Goodness of Fit Measurement Model of GOJEK Application Continuance Usage

\begin{tabular}{lllll}
\hline N & Model & Criteri & Result & Goodness of \\
o & Fit & a & & Fit \\
\hline 1 & CMIN/D & $\leq 2$ & 1.444 & Good Fit \\
& F & & & \\
\hline 2 & RMSEA & $\leq 0.08$ & 0.038 & Good Fit \\
\hline 3 & GFI & $0.8-$ & 0.853 & Marginal Fit \\
& & 0.9 & & \\
\hline 4 & CFI & $\geq 0.9$ & 0.945 & Good Fit \\
\hline 5 & TLI & $\geq 0.9$ & 0.939 & Good Fit \\
\hline
\end{tabular}

In this research, the variables are categorized as valid because of the AVE value is greater and equal to 0.5 and the Construct Reliability (CR) value is greater than 0.7 (Hair et al., 2010). 


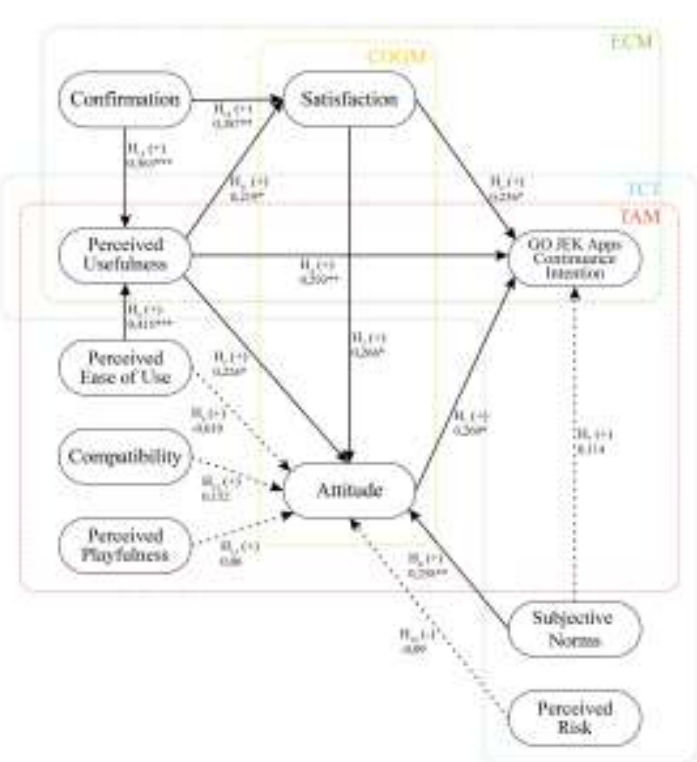

Fig.2. Result of Structural Model

Note: The number shows the standardized estimates

$* * * \mathrm{p}$ value $<0.001 ; * * \mathrm{p}$ value $<0.01$

$*$ p value $<0.05$

Table 2: Goodness of Fit Structural Model of GOJEK Application Continuance Usage Intention

\begin{tabular}{|c|c|c|c|c|}
\hline $\begin{array}{l}\mathbf{N} \\
\mathbf{0}\end{array}$ & $\begin{array}{l}\text { Model } \\
\text { Fit } \\
\end{array}$ & $\begin{array}{l}\text { Criteri } \\
\text { a }\end{array}$ & $\begin{array}{l}\text { Resul } \\
\mathbf{t}\end{array}$ & $\begin{array}{l}\text { Goodness of } \\
\text { Fit }\end{array}$ \\
\hline 1. & $\begin{array}{l}\text { CMIN/ } \\
\text { DF }\end{array}$ & $\leq 2$ & 1.454 & Good Fit \\
\hline 2. & $\begin{array}{l}\text { RMSE } \\
\text { A }\end{array}$ & $\leq 0.08$ & 0.039 & Good Fit \\
\hline 3. & $\mathrm{I}^{\mathrm{GF}}$ & $\begin{array}{l}0.8 \\
0.9 \\
\end{array}$ & 0.853 & Marginal Fit \\
\hline 4. & $\mathrm{I}^{\mathrm{CF}}$ & $\geq 0.9$ & 0.906 & Good Fit \\
\hline 5. & $\begin{array}{ll} & \text { TL } \\
\text { I } & \\
\end{array}$ & $\begin{array}{l}0.8 \\
0.9\end{array}$ & 0.897 & Marginal Fit \\
\hline
\end{tabular}

Table 3: Hypotheses Testing of GOJEK Application Continuance Usage Intention

\begin{tabular}{llllll}
\hline $\begin{array}{l}\text { Hypoth } \\
\text { esis }\end{array}$ & Influenc & $\begin{array}{l}\text { Path } \\
\text { e }\end{array}$ & $\begin{array}{l}\text { C.R } \\
\text { Coefficient }\end{array}$ & $\begin{array}{l}\text { P- } \\
\text { Value }\end{array}$ & Result \\
\hline H1 $(+)$ & ATT $\rightarrow$ C & 0.269 & 2.13 & 0.03 & Accepted \\
& I & & 2 & 3 & \\
\hline H2 (+) & SAT $\rightarrow$ C & 0.236 & 2.13 & 0.02 & Accepted \\
& I & & 2 & 2 & \\
\hline
\end{tabular}




\begin{tabular}{llllll}
\hline H3 (+) & SAT $\rightarrow$ A & 0.266 & 2.28 & 0.00 & Accepted \\
& TT & & 7 & 6 & \\
\hline H4 (+) & PU $\rightarrow$ CI & 0.293 & 3.13 & 0.00 & Accepted \\
& & & 6 & 2 & \\
\hline H5 (+) & PU $\rightarrow$ AT & 0.226 & 2.28 & 0.02 & Accepted \\
& T & & 3 & 2 & \\
\hline H6 (+) & PEU $\rightarrow$ A & -0.019 & - & 0.86 & Not \\
& TT & & 0.172 & 3 & Accepted \\
\hline H7 (+) & SN $\rightarrow$ CI & 0.114 & 1.27 & 0.20 & Not \\
& & & 3 & 3 & Accepted \\
\hline H8 (+) & SN $\rightarrow$ AT & 0.258 & 2.74 & 0.00 & Accepted \\
& T & & 7 & 6 & \\
\hline H9 (+) & PEU $\rightarrow$ P & 0.415 & 5.7 & $* * *$ & Accepted \\
& U & & & & \\
\hline H10 (-) & PR $\rightarrow$ AT & -0.09 & - & 0.24 & Not \\
& T & & 1.155 & 8 & Accepted \\
\hline H11 (+) & PU $\rightarrow$ SA & 0.219 & 2.28 & 0.02 & Accepted \\
& T & & 2 & 2 & \\
\hline H12 (+) & CON $\rightarrow$ S & 0.387 & 3.12 & 0.00 & Accepted \\
& AT & & & 2 & \\
\hline H13 (+) & CON $\rightarrow$ P & 0.363 & 3.92 & $* * *$ & Accepted \\
& U & & 2 & & \\
\hline H14 (+) & C $\rightarrow$ ATT & 0.152 & 1.51 & 0.12 & Not \\
& & & 8 & 9 & Accepted \\
\hline H15 (+) & PPF $\rightarrow$ A & 0.06 & 0.65 & 0.51 & Not \\
& TT & & 8 & 0 & Accepted \\
\hline
\end{tabular}

In the table 3, almost the entire hypotheses are accepted except H6, H7, H10, H14, and $\mathrm{H} 15$ are not accepted.

The influence of users' perceived ease of use on users' attitudes towards using GOJEK Application is not accepted, with C.R Value -0.172 and P-Value is 0.863 . H6 is not accepted, because of this research found by using GOJEK Application for three months has made user to be more familiar within the application, then it would not increase the attitude towards GOJEK Application.

The influence of GOJEK Application users' subjective norm on users' continuance usage intention is not accepted, with C.R Value 1.273 and P-Value is 0.203. H7 is not accepted, research found users tended to make decisions according to users' own opinion or experience after first usage, thus subjective norms played nonsignificant role on continuance intention.

The negative influence of users' perceived risk on users' attitudes towards using GOJEK Application is not accepted, with C.R Value -1.155 and P-Value is 0.248. H10 is not accepted, this research found Perceived risk did not influence users' attitude towards GOJEK Application when users are already feeling satisfied with the application, receiving recommendations about the application from others, being more productive when using GO-JEK Application.

The influence of users' compatibility on users' attitudes towards using GOJEK Application is not accepted, with C.R Value 1.518 and P-Value is 0.129 . H14 is not 
accepted, this research found when users feel that GOJEK Application is useful, compatibility does not influence users' attitude towards using the application.

The influence of users' perceived playfulness on users' attitudes towards using GOJEK Application is not accepted, with C.R Value 0.658 and P-Value is 0.510. H15 is not accepted because of perceived playfulness did not influence users' attitude towards GO-JEK Application when users are already feeling satisfied with the application, receiving recommendations about the application from others, being more productive when using GO-JEK application also GO-JEK Application is not an entertainment application but as a tool application.

\section{Conclusion}

The result of this study indicates that satisfaction, perceived usefulness and attitudes influence GO-JEK application continuance usage intention. However, perceived usefulness has the greatest influence directly on continuance usage intention. Convenience when taking taxi or usefulness of GO-JEK application increases users intention to continue using the application. Attitude towards using GOJEK Application also has an influence on continuance usage intention but not as strong as perceived usefulness. Thus, this will generate profit to GOJEK application. In addition, GOJEK will improve the livelihoods and welfare of workers in a variety of informal sectors in Indonesia.

The management of GOJEK Application should focus on the maximum functionality of the application to provide services efficiently with different needs and expectation of users. Complaint such as software bugs and other problems should be prevented by doing software development and update more frequently. The management of GOJEK Application should invest more in advertising, since media and advertising formed users' attitude towards using the application. In addition, users' attitude is one of the important variables influence users continuance usage intention. Lee (2010) stated that attitude is built by potentially from information passed by others, media and advertising.

Future research can be conducted in another city to show difference result in different area. Future research can use other object such as Grab so the result will be used as a comparison. This research only examines confirmation, perceived usefulness, perceived ease of use; the future research should investigate the determinants of those variables Weng et al. (2017). Variable perceived playfulness should not be included as variable to investigate a tool application. However, perceived playfulness could be included as variable to investigate entertainment application such as Instagram and Facebook.

\section{References}

[1] Ahn, T., Ryu, S., \& Han, I. (2007). The Impact of Web Quality and Playfulness on User Acceptance of Online Retailing. Information \& Management , 44 (3), 263-275.

[2] Ajzen, I. (1991). The Theory of Planned Behavior. Organizational Behavior and Human Decision Processes, 50 (2), 179-211.

[3] Bashir, I., \& Madhaviah, C. (2015). Consumer Attitude and Behavioral Intention Towards Internet Banking Adoption in India. Journal of Indian Business Research , 7 (1), 67-102. 
[4] Bhattacherjee, A. (2001). Understanding Information Systems Continuance: an Expectation-Confirmation Model. MIS Quarterly, 25 (3), 74-94.

[5] Chan, J. W., Chang, V. L., Lau, W. K., Law, L. K., \& Lei, C. J. (2016). Taxi App Market Analysis in Hongkong. Journal Economy Business Management , 4 (3), 239-242.

[6] Chen, C.-C., Lee, C.-H., \& Hsiao, K.-L. (2018). Comparing the Determinants of Non-MOOC and MOOC Continuance Intentoin in Taiwan: Effects of interactivity and Openness. Library Hi Tech .

[7] Currás-Pérez, R., Ruiz-Mafé, C., \& Sanz-Blas, S. (2013). Social Network Loyalty: Evaluating the Role of Attitude, Perceived Risk, and Satisfaction. Online Information Review , 37 (1), 61-82.

[8] Davis, F. D., Bagozzi, R. P., \& Warshaw, P. (1992). Extrinsic and Intrinsic Motivation to User Computers in the Workplace. Journal of Applied Social Psychology, 22 (14), 1111-1132.

[9] Gilani, M. S., Iranmanesh, M., Nikbin, D., \& Zailani, S. (2017). EMR Continuance Usage Intention of Healthcare Professionals. Information Health Social Care , 42 (2), 153-165.

[10] Hair, J. F., Black, W. C., Babin, B. J., \& Anderson, R. E. (2010). Multivariate Data Analysis: A Global Perspective (Vol. 7). London: Pearson Education.

[11] Jain, L., Kumar, H., \& Singla, R. K. (2014). Assesing Mobile Technology Usage for Knowledge Dissemination among Farmers in Punjab. Information Technology for Development, 21 (4), 1-9.

[12] Keong, W. Y. (2016). Factors Influencing Passengers' Attitude and Adoption Intention of Mobile Taxi Booking. The Social Science, 11 (11), 2769-2776.

[13] Lee, C.-Y., Tsao, C.-H., \& Chang, W.-C. (2015). The Relationship Between Attitude toward Using and Customer Satisfaction with Mobile Application Services. Journal of Enterprise Information Management, 28 (5), 680-697.

[14] Lee, Y. H., Hsieh, Y. C., \& Chen, Y. H. (2013). An Investigation of Employees' Use of E-Learning Systems: Applying the Technology Acceptance Model. Behavioral \& Information Technology, 32 (2), 173-189.

[15] Liao, C., Chen, J.-L., \& Palvia, P. (2009). Information Technology Adoption Behavior Life Cycle: Toward a Technology Continuance Theory (TCT). International Journal of Information Management , 29 (4), 309-320.

[16] Lin, C. S., Wu, S., \& Tsai, R. J. (2005). Integrating Perceived Playfulness into Expectation-Confirmation Model for Web Portal Context. Information \& Management , 42 (5), 683-693.

[17] Oghuma, A. P., Libaque-Saenz, C. F., Wong, S. F., \& Chang, Y. (2016). An Expectation-Confirmation Model of Continuance Intention to Use Mobile Instant Messaging. Telematics and Informatics , 33 (1), 34-47.

[18] Oliver, R. L. (1980). A Cognitive Model of the Antecendents and Consequences of Satisfaction Decisions. Journal Marketing Research, 17 (4), 460-469.

[19] Peng, L., Wang, H., He, X., Guo, D., \& Lin, Y. (2014). Exploring Factors Affecting the User Adoption of Call-taxi App. Proceedings of the 25th Australasian Conference on Information Systems, 8th - 10th December, Auckland, New Zealand. ACIS.

[20] Soemantadiredja, A., Vitayala, A., \& Hermadi, I. (2015). Analysis Adoption of Innovation Go-jek Application. International Journal of Science and Research, 6(3), 936-940. 
[21] Srivastava, K., \& Sharma, N. K. (2011). Exploring the Multidimensional Role of Involvement and Perceived Risk in Brand Extension. International Journal of Commerce and Management , 21 (4), 410-427.

[22] Susanto, A., Chang, Y., \& Ha, Y. (2016). Determinants of Continuance Intention to Use the Smartphone Banking Services: An Extension to the Expectation - Confirmation Model. Industrial Management \& Data Systems, $116(3), 508-525$.

[23] Tarkianen, A., \& Sundqvist, S. (2005). Subjective Norms, Attitudes and Intentions of Finnish Consumers in Buying Organic Food. British Food Journal 107 (11), 808-822.

[24] Weng, G. S., Zailani, S., Iranmanesh, M., \& Hyum, S. S. (2017). Mobile Taxi Booking Application Service's Continuance Usage Intention by Users. Transportation Research Part D , 57, 207-216. 